\title{
Retraction Note: Design of green city landscape based on GIS system
}

Jing Zhao'

Published online: 23 November 2021

(c) Saudi Society for Geosciences 2021

Retraction Note: Arabian Journal of Geosciences (2021) 14: 514

https://doi.org/10.1007/s12517-021-06716-0

The Editor-in-Chief and the Publisher have retracted this article because the content of this article is nonsensical. The peer review process was not carried out in accordance with the Publisher's peer review policy. The author has not responded to correspondence regarding this retraction.

The original article can be found online at https://doi.org/10.1007/ s12517-021-06716-0.

Jing Zhao

zhaojing_82@126.com

$1 \quad$ Art and Design College, Nanjing Institute of Railway

Technology, Nanjing 210000, Jiangsu, China 